\title{
INFORMACIÓN COLABORADORES
}




\section{INFORMACIÓN AUTORES}

Álvaro Acevedo Tarazona

Universidad Industrial de Santander

Doctor en Historia

E-mail: tarazona20@gmail.com

Olga Yanet Acuña Rodríguez

Universidad Pedagógica y Tecnológica de Colombia

Doctora en Historia de América Latina

E-mail: olgayanet@gmail.com

Miryam Báez Osorio

Universidad Pedagógica y Tecnológica de Colombia

Doctora en Ciencias de la Educación-RUDECOLOMBIA

E-mail:mbaezosorio@yahoo.es

Remedios Ferrero Micó

Universidad de Valencia (España)

Doctora en Derecho

E-mail: remedios.ferrero@uv.es

\section{Bárbara García Sánchez}

Universidad Distrital

Doctora en Ciencias de la Educación-RUDECOLOMBIA

E-mail: barbaragarciasanchez@yahoo.com

Jesús García Mínguez

Universidad de Granada (España)

Doctor en Filosofía

E-mail:jminguez@ugr.es

Javier Guerrero Barón

Universidad Pedagógica y Tecnológica de Colombia

Doctor en Historia

E-mail: jguerrer99@hotmail.com

Javier Ocampo López

Universidad Pedagógica y Tecnológica de Colombia

Doctor en Ciencias de la Educación-RUDECOLOMBIA

E-mail: Javierocampo11@yahoo.es 


\section{Rina Alexandra Restrepo}

Universidad Tecnológica de Pereira

Magíster en Literatura y Filosofía

E-mail: rinaalexandra@gmail.com

Antonio Sillau Pérez

Universidad de Córdoba (Argentina)

Magíster en Ciencia Política

E-mail: ansiper@hotmail.com

\section{Diana Elvira Soto Arango}

Universidad Pedagógica y Tecnológica de Colombia

Doctora en Filosofía y Ciencias de la Educación

E-mail: dianaelvirasoto@gmail.com

Morelos Torres Aguilar

Universidad Autónoma de Chiapas (México)

Doctor en Historia

E-mail: morelostorres@gmail.com

\section{Belin Vázquez}

Universidad del Zulia (Venezuela)

Doctora en Historia de América

E-mail: belinvazquez@cantv.net

\section{María Cristina Vera de Flachs}

Universidad de Córdoba (Argentina)

Doctora en Historia

E-mail:vera@onenet.com.ar 


\title{
INFORMACIÓN Y NORMAS PARA AUTORES
}

\author{
NORMAS PARA LA PUBLICACIÓN \\ DE ORIGINALES EN \\ REVISTA "Historia de la Educación \\ Latinoamericana". 2009
}

ISSN: 0122-7238. Indexada en LATINDEX por COLCIENCIAS: 01227238, agosto del 2001. Ratificada, sucesivamente. Última indexación. 2008

\section{Normas para el envío de originales}

1. Los artículos deben ser inéditos. Tendrán una extensión máxima de 30 folios a doble espacio, con un máximo de 70.000 caracteres, incluidos cuadros, gráficos, notas, imágenes relacionadas con el tema, apéndices y bibliografía. La clasificación de los artículos que se presentan en ésta revista son: Científicos; Reflexión y de Revisión. Las reseñas de los libros tendrán un mínimo de dos cuartillas y un máximo de cuatro. Se debe incluir la carátula. Para reseñar revistas, es indispensable que envíen el número que se va a reseñar.

2. Cada trabajo irá precedido de una hoja donde se incluirá el resumen del Currículo Vital del Autor. Se incluye: Nombre, lugar de trabajo, dirección, E-mail, tel, fax; estatus profesional, línea de investigación y publicaciones de los últimos cinco años de Libros y Revistas, las publicaciones deben incluir ISBN ó el ISSN. (Los datos particulares no serán publicados).

3. Las colaboraciones podrán remitirse en cualquiera de las lenguas oficiales de la Revista: español y portugués. Con todo, al comienzo del trabajo se incluirá dos resúmenes máximos de 5 renglones, uno en español, otro en inglés. Asimismo, se indicarán las palabras clave en ambos idiomas (concisas, si puede ser una sola mejor). Además, todo el artículo se enviará en ingles para la versión electrónica en página Web.

4. Solo se aceptarán apéndices documentales muy breves y en casos justificados.

5. Las notas deberán ir numeradas correlativamente, en caracteres arábigos, voladas sobre el texto e insertas a pie de página.

6. Las referencias bibliográficas observarán la siguiente secuencia: 


\section{Para libros}

OCAMPO LÓPEZ, Javier. (2001): Rafael Bernal Jiménez. Sus ideas educativa, sociológicas humanísticas y la escuela nueva en Boyacá. Colección: Pedagogos colombianos y latinoamericanos No. 1. Bogotá, Rudecolombia, Universidad Pedagógica y Tecnológica de Colombia, Plaza y Janés. IIFA.

\section{Capítulos de libros}

SALDAÑA, Juan José. (1995): Ilustración ciencia y técnica en América, en La Ilustración en la América Colonial. Soto Arango, Diana. PUIG-SAMPER, Miguel Ángel y ARBOLEDA, Luís Carlos. Madrid. Consejo Superior de Investigaciones Científicas. Doce Calles. Conciencias, p.106.

\section{Para artículos}

SOTO ARANGO, Diana Elvira. (2005) “Aproximación histórica a la universidad Colombiana", en Revista Historia de la Educación Latinoamericana. No. 7. Tunja, Universidad Pedagógica y Tecnológica de Colombia. RUDECOLOMBIA, pp. 25-62.

Una vez citada, del modo acá descrito, determinada obra, puede emplearse en ulteriores citas de la misma forma abreviada que incluye sólo el apellido del autor, año de publicación y página donde aparece la cita.

7. La Secretaría de la revista acusará recibo de los trabajos en el plazo de diez días a partir de la fecha de recepción. Tras la pertinente evaluación, por dos pares académicos, el Consejo de Redacción comunicará su resolución a los interesados.

8. Se adjuntará un resumen del currículo del autor o de los autores que consiste sólo en lo siguiente: Nombre, máximo título académico; institución donde trabaja; publicaciones solo de los últimos cinco años, señalando si es libro o artículo; premios y menciones honoríficas. E-mail.

9. Los autores recibirán pruebas de imprenta para su corrección, debiendo proceder a la misma en un plazo máximo de quince días. Los autores enviarán vía Internet su artículo. Si es relacionado harán entrega del Copyright de Artículo a la Revista.

10. Los autores recibirán dos ejemplares de la revista.

11. Se publicarán recensiones de aquellos libros que lleguen como donación. 


\title{
REQUISITOS DE EDICIÓN
}

Dentro de este orden, a fin de facilitar las tareas de edición/impresión, se encarece la observación de las siguientes pautas:

1. Los trabajos se enviarán vía correo electrónico: publicacioneshisula@gmail.com.

2. Se utilizará como fuente Timen New Roman, tamaño 12 puntos, pudiendo variar este patrón en función de los distintos niveles jerárquicos del texto.

3. No se recomienda el empleo de símbolos o signos procedentes de fuentes de origen alfabético cirílico, griego y en general, las de procedencia oriental. En caso de necesidad, los textos de esa naturaleza deberán de ser procesados como imágenes. Para destacar palabras o textos se usará exclusivamente cursiva, no negrilla ni subrayado.

4. En caso de remisión se imágenes, deberán incrustarse, no vincularse, en el documento. A este respecto, se recomiendan el empleo del formato JPEG, la inserción en blanco y negro y su preferente agrupación en las páginas finales. Siempre que sea posible, los archivos que contengan imágenes usadas en el documento se entregarán junto con el mismo.

\section{INFORMATION AND REGULATIONS FOR AUTHORS}

\section{REGULATIONS FOR THE PUBLICATION OF ORIGINAL WORKS IN THE ISSUE}

"Historia de la Educación Latinoamericana" 2009

\author{
ISSN: 0122-7238. Indexed In LATINDEX by COLCIENCIAS: 01227238, \\ August 2001. Confirmed consecutively. Last indexation 2008
}

\section{Regulations for submitting the original works}

1. The articles must be unpublished. They will have a Maxim extension of 30 folios to double-spaced, with a maximum of 70,000 characters, including pictures, graphs, notes, images related to the subject, appendices and bibliography. The articles classification is are: Scientific, Reflexion and Revision. Books review will have a minimum of two pages and a maximum of four. The title page is due to include. In order to review magazines, it is indispensable to send the number that is going to be reviewed.

2. Each work must be sent with a letter that includes the summary of the Author's 
Curriculum Vitae. It must include: Name, work place, address, email, telephone number, fax, professional status, research line and publications of books and magazines throughout the last five years. The publications must include ISBN or the ISSN. (The particular data will not be published).

3. The papers will be sent in any of the official languages of the Issue: Spanish and Portuguese. The article must contain two summaries of maximum 5 lines must be included at the beginning, one in Spanish, another in English. Also, the key words in both languages might be included (The fewer words the better). In addition, all the article will be sent in English for the electronic version in the Web page.

4. Documentary appendices will only be accepted provided they are very brief and necessary.

5. The notes will have to be co-relatively numbered, in Arabic characters, placed on the text and inserted as foot page.

6. The bibliographical references will contain the following sequence:

\section{For Books}

OCAMPO LÓPEZ, Javier. (2001): Rafael Bernal Jiménez. Sus ideas educativa, sociológicas humanisticas y la escuela nueva en Boyacá. Colección: Pedagogos colombianos y latinoamericanos No. 1. Bogotá, Rudecolombia, Universidad Pedagógica y Tecnológica de Colombia, Plaza y Janés. IIFA.

\section{Chapters of Books}

SALDAÑA, Juan José. (1995): Ilustración ciencia y técnica en América, en La Ilustración en la América Colonial. Soto Arango, Diana. PUIG-SAMPER, Miguel Ángel y ARBOLEDA, Luís Carlos. Madrid. Consejo Superior de Investigaciones Científicas. Doce Calles. Conciencias, p.106.

\section{For Articles}

SOTO ARANGO, Diana Elvira. (2005) "Aproximación histórica a la universidad Colombiana", en Revista Historia de la Educación Latinoamericana. No. 7. Tunja, Universidad Pedagógica y Tecnológica de Colombia. RUDECOLOMBIA, pp. 25-62.

Once the article is quoted, in the way described here, it can be used in later cites in the same brief form that includes only the last name of the author, year of publication and page where the quote appears. The article will be placed at the end.

7. The Secretary of the issue will confirm the reception of the articles in the term of ten days from the date of reception. After the pertinent evaluation done by two academic peers, the Editorial Committee will communicate their approval to the interested ones. 
8. A summary of the author's CV must include: Name, highest degree, work place, publications from the last five years only, indicating if it is a book or an article, awards and honors and E-mail.

9. The authors will receive drafts of the press for their correction, having had to come to the same one in a maximum term of fifteen days. The authors will send via Internet their article. If it is to be published, the authors must deliver the Copyright of the Article to the Issue.

10. The authors will receive two printed versions of the issue.

11. Reviews of those books submitted as donation will be published.

\section{Edition Requirements}

\section{In order to facilitate the edition/printing activities, it is necessary to keep in mind the following guidelines:}

1. The paper must be sent via e-mail: publicacioneshisula@gmail.com.

2. The font will have to be Times New Roman, size 12 points, which may vary according to the different hierarchic levels in the text.

3. The use of symbols or signs from sources of alphabetical origin such as Cyrillic, Greek, and in general, those of Eastern origin is not advised. In case of necessity, these kind of texts will be processed as images. In order to enhance words or texts, Italics, neither bold type nor underlining will be used exclusively.

4. In the case of sending images, they will have to be incrusted, not linked, in the document. To this respect, it is recommended the use of format JPEG, the insertion in black and white colors and its grouping in the final pages. Whenever possible, the archives that contain images used in the document must be sent along with it. 


\section{FORMATOS}

\begin{tabular}{|c|}
\hline $\begin{array}{c}\text { FORMATO DE SUSCRIPCIÓN } \\
\text { REVISTA HISTORIA DE LA } \\
\text { EDUCACIÓN LATINOAMERICA }\end{array}$ \\
\hline Nombre: \\
\hline Dirección: \\
\hline Ciudad / Departamento - Provincia: \\
\hline Código Postal: \\
\hline Teléfono: \\
\hline $\begin{array}{c}\text { TASAS DE SUSCRIPCIÓN } \\
\text { Valor } \$ 20.000 . \text { oo más gastos de envío. }\end{array}$ \\
\hline $\begin{array}{c}\text { FORMA DE PAGO } \\
\text { Consignación a la cuenta corriente de ALMA MATER - RUDECOLOMBIA, } \\
\text { Doctorado en Educación. Bancolombia No. } 178-271458-67\end{array}$ \\
\hline Firma: \\
\hline $\begin{array}{l}\text { Haga llegar este formato con la copia de la cosignación a las oficinas del Doctorado en Educación. } \\
\text { Avenida Central del Norte, Oficina C } 335 \text {. Tunja, Boyacá - Colombia. Órdenes telefónicas al 57-8-7448215 }\end{array}$ \\
\hline
\end{tabular}


Copyright

\section{REVISTA HISTORIA DE LA EDUCACIÓN LATINOAMERICA}

Artículo

Autor(es)

Fecha

Por el presente documento, cedo el Copyright del artículo arriba indicado para la, Revista

Historia de la Educación Latinoamericana

identificada con ISSN: 0122-7238.

El documento se hará efectivo cuando

el trabajo sea aceptado, por el Comité Editorial.

Confirmo también que el escrito no contiene materia cuya publicación viole algún copyright u otro derecho personal o de propiedad de cualquier persona o entidad.

Firma:

Documento de Identidad:

Nota: el trabajo no será procesado para la publicación hasta que los editores académicos reciban este impreso diligenciado.

Si el artículo no es publicado en la Revista Historia de la Educación

Latinoamericana, este documento no tendrá efecto alguno. 
Esta Revista se terminó de imprimir en el

Grupo Imprenta y Publicaciones de la Universidad

Pedagógica y Tecnológica de Colombia, en julio de 2009

con un tiraje de 500 ejemplares.

Tunja, Boyacá - Colombia 